\title{
Foreign direct investment and economic growth in Malaysia : interactions with human capital and financial deepening
}

\begin{abstract}
This paper explores the role of foreign direct investment (FDI) in economic growth in Malaysia, appropriately controlling for other proximate drivers of economic growth: domestic investment, exports, financial markets, and human capital. Domestic capital formation, FDI, human capital, and financial deepening significantly affect economic growth. FDI has a positive and significant effect on economic growth, but its effect is of lesser magnitude than that of domestic investment. Human capital and financial markets interact with FDI and, thus, are important for both short- and long-term growth processes. The results suggest that it is important to encourage domestic as well as foreign investment to put Malaysia back on its precrisis growth path.
\end{abstract}

Keyword: Domestic investment; Economic growth; FDI; Financial markets 